\title{
The Thermogeographic Model in Paleogeography: Application of an Abiotic Model to a Plate Tectonic World
}

\author{
Lee-Ann C. Hayek ${ }^{1}$ and Walter H. Adey ${ }^{2}$ \\ ${ }^{1}$ National Museum of Natural History, Statistics and Mathematics, \\ ${ }^{2}$ National Museum of Natural History, Department of Botany, \\ Smithsonian Institution, Washington D.C. \\ USA
}

\section{Introduction}

\subsection{Marine biogeography and paleoecology}

Recent coastal marine biogeography has a long and venerable history. (Ekman, 1953; Briggs, 1974, 1995; Vermejj, 1978). However, it has lacked a substantial theory and has been the subject of widespread criticism (Longhurst, 1998; Rosenzweig, 1995). The most recent research, driven by the need for coastal conservation, has added satellite remote sensing and constructions based on present day sea surface temperature (Spalding et al, 2007). Based on largely subjectively-created assemblages of organisms and sea surface temperatures (SST), these studies are increasingly sophisticated creating hundreds of ecoregions where previously biogeography researchers had created dozens. However, mostly they fail to consider that macro-organism distribution, the focus of virtually all biogeographical analyses, has not developed solely based on SST characteristics that have lasted for only a few millennia at most. The evolution of stable assemblages of macro-organisms requires geological time, since it is based in the evolution of its component organisms.

In paleoecological analysis, understanding the present has always been regarded as a key to the past and modern studies normally make that connection (Brenchley and Harper, 1998). However, paleoecological analyses by definition, treats change with geological time and is based in the evolution of organisms, typically over millenia to millions of years. When the analog is coastal biocoenoses, the modern analog studies are mostly fixed Intime. Coastal Thermogeographic Regions as defined by the Adey and Steneck (2001) five-dimensional abiotic model (TM). The principal variables were mean minimum and maximum surface temperature, with coastal area over time (present and 18K) appearing as contours. Isolation by oceans and continents, i.e., northern and southern and Atlantic and Pacific/Indian Oceans, were introduced by separating the main diagram into quadrants, and then stretching some overlapping coasts. The strength of each Region is represented by the number of contours of coastal area that is constant over Pleistocene time. 
Coastal thermography (Present $x$ 18K area)

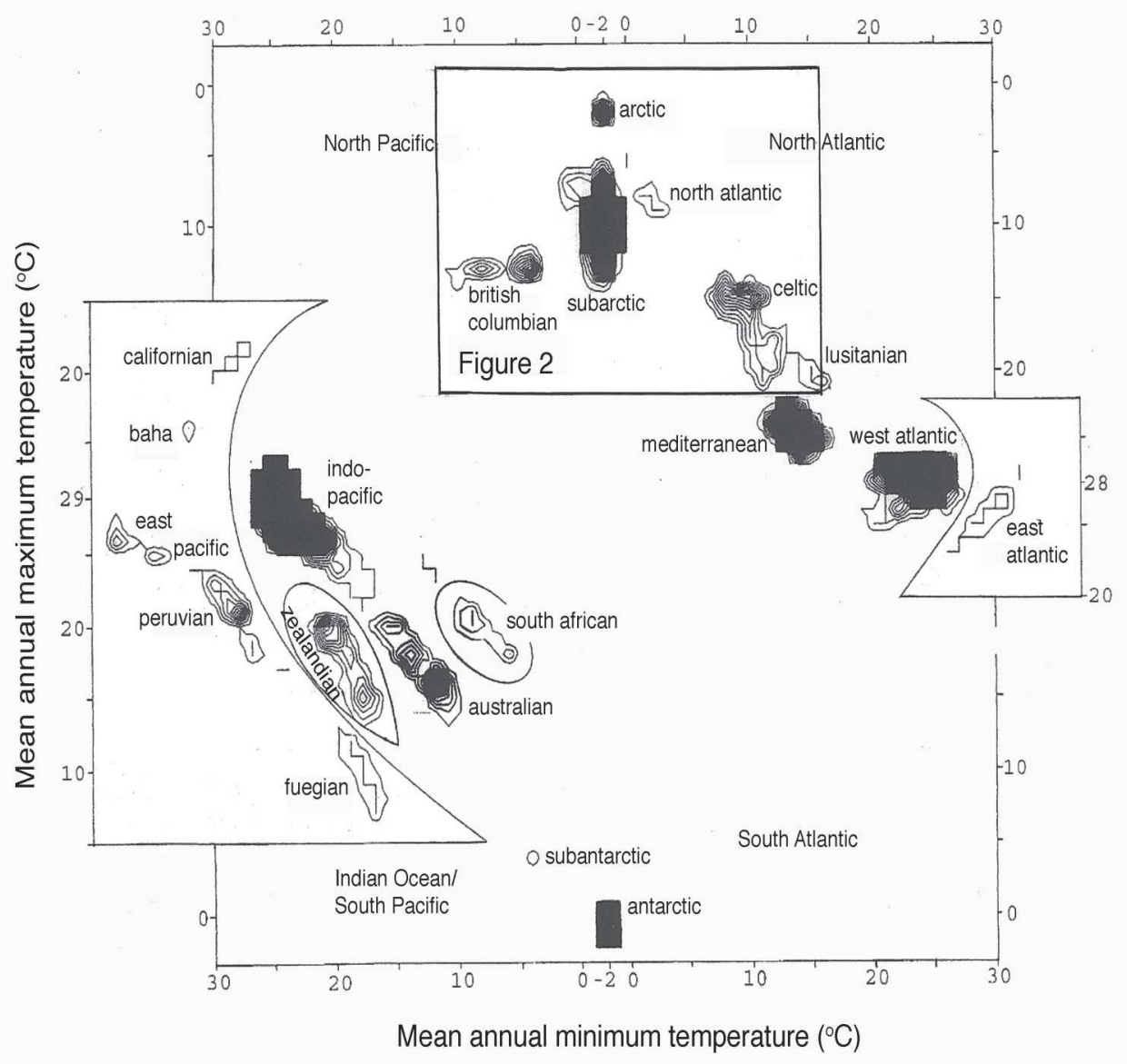

Fig. 1. Coastal Thermogeographic Regions

\subsection{Thermogeography over time}

Adey and Steneck (2001) developed a time-integrated thermogeographic model to demonstrate why benthic marine algal assemblages of coastal rocky marine, sublittoral zones, develop biogeographic patterns in their distribution and abundance. The TM is a predictive, abiotic model in which the maximum and minimum sea surface temperatures (sea climate) are tabulated and plotted for each nautical mile of rocky coastline for both the present (1955) and the Last Glacial Maximum (LGM) (CLIMAP, 1976; see Adey and Steneck, 2001). These two alternate states (glacial and interglacial) characterize the principal climatic character of the global marine realm since late Pleistocene time (0.7-1.8 Ma); it is during this time that most living species have evolved (Briggs, 1995). Some sea climates (specific thermal regimes) have a large amount of coast; others none. Some sea climates with large 
coastal areas remain more or less constant through Pleistocene time, while other sea climates are absent or ephemeral (lacking major coastlines over Pleistocene time). When the sea climate/coastal area contour diagrams for LGM (glacial) and Present (interglacial) times are mathematically integrated, a contour diagram results (Fig. 1.) which is the Thermogeographic Model. In paleoecological and ecological study, the identification of unique biofacies boundaries and the structure of the assemblages on either side of those boundaries is critical to identifying environmental changes with time. With the application of SHE we show an expansion of the results of the TM and provide a framework for examining the distinct biofacies based upon their species composition.

The resulting thermogeographic model (TM; Fig. 1) defines 20 regions that correspond with the cores of 24 traditionally recognized biogeographic regions determined by published distributions of organisms. The four remaining classical regions were weak and disputed or lacked significant rocky shore. In the colder North Atlantic, the primary traditionally defined regions (e.g., Briggs, 1974), the Western Atlantic Boreal and the Eastern Atlantic Boreal are represented by equivalent regions in the Thermogeographic Model (TM) (Subarctic-west; Boreal or Celtic-east). However, the boundaries of those regions in the western Atlantic are markedly different between the classical organism-defined approach (Cape Hatteras to the Strait of Belle Isle; Briggs 1974), and the physical/time model (Newfoundland and northern Gulf of St. Lawrence to central Labrador, TM, Adey and Steneck, 2001). (Fig. 2).

Thermogeographic regions (TRs), although clearly correlated with most classical biogeographic regions, have many shapes in area/sea climate space, from elliptical to twoor three-lobed. In a few cases, two relatively strong TRs are conjoined by a narrow isthmus. Most striking, however, is that $10-20 \%$ of the world's coastlines do not belong to any TR. These transitional zones result from shifting Pleistocene climates and their contained coastlines. An important finding of the TM is that the rocky western North Atlantic Coast from Long Island Sound through the Gulf of Maine, and the southern Gulf of St. Lawrence comprises one of these transitional zones (Adey and Steneck, 2001, see their Fig. 7).

Adey and Steneck (2001) also proposed that biogeographic patterns should be determined by quantitatively analyzing community assemblages. They tested the efficacy of thermogeographic regions, as determined by the abiotic TM, with abundance-determined patterns in the distribution of crustose coralline red algae (Rhodophyta/Corallinales) in the colder part of the northern hemisphere. The corallines have special relevance to paleoecology in that they have a fossil history dating back to the Mesozoic and perhaps earlier (Johansen, 1981). By mid-Tertiary they are rock-formers and important index fossils (Bassi and Nebelsick, 2010). Adey and Hayek (2011) also validated the TM by using a large data set for fleshy seaweed assemblages in the same regions in the NW Atlantic. Their analysis used several test statistics and models for validation, and provided a pictorial summary diagram based in the Bray Curtis similarity matrix (Fig. 3).

Herein we use the biomass sample data from Adey and Hayek (2011) to test the biofacies determined by the TM. We analyze this data and compare the individual depth biofacies to the TM results. We use an approach called SHE (Hayek and Buzas, 1997; 2010) Analysis that was developed specifically for biofacies identification Buzas and Hayek, 1998) uses all aspects of the taxon data as advocated by Adey and Steneck (2001). Using this method in combination with a new conditional biofacies boundary indicator of taxon importance termed CoBBI our results show strong support for the TM at all depths in this biogeographic region of the North Atlantic. 


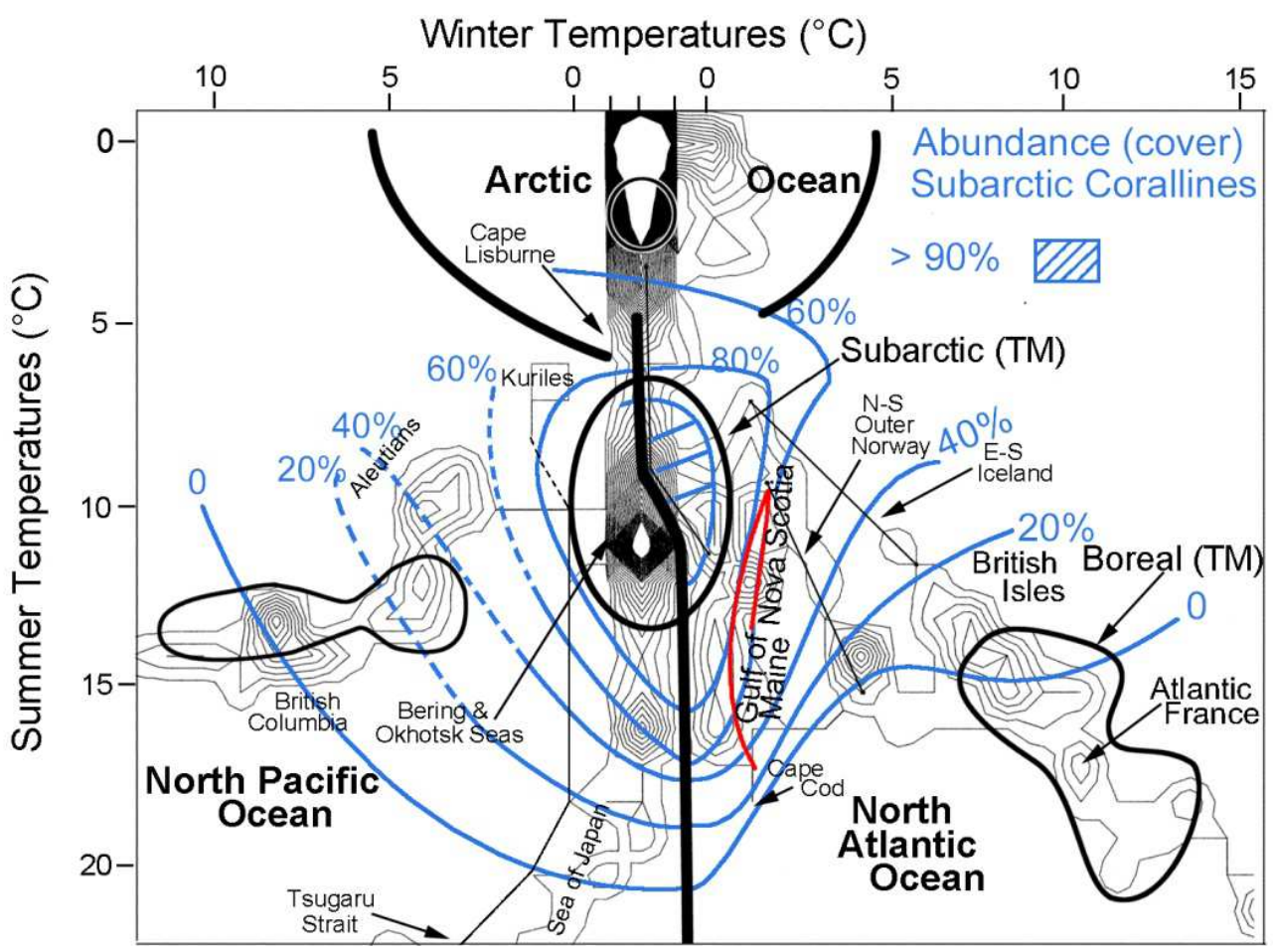

Fig. 2. The distribution of Subarctic crustose coralline algal cover (blue contours) on a background of present-day coastal area distribution as a function of summer-winter temperatures as determined in the Adey and Steneck (2001) TM. The background diagram shows the temperate to Arctic coastal area/temperature distribution with the resultant thermogeographic regions (ellipses) superimposed. The location of "core" Subarctic Coast (northern Gulf of St. Lawrence; northeastern NF and Labrador) is shown as a light black line on the left side of the North Atlantic Subarctic ellipse. The line extends nearly to the Arctic circle, as it includes northern Labrador. The Gulf of Maine and Nova Scotia are shown as red lines with their intersection representing the Bay of Fundy.

Based in repeated successful tests of the validity of the TM, and our rapidly increasing knowledge of past shoreline configuration, grounded in plate tectonics, and our knowledge of past SST, centered on oceanic sediment microfossils, it is now possible to extend the biogeography of the TM into the past, provide an over-arching theory for paleobiogeography and link the very patchy information of marine paleoecology.

\section{Methods}

\subsection{Sampling}

With the intention of comparing seaweed populations in the Subarctic Region (NLQ) (as determined by the Thermogeographic Model) with those in the Subarctic/Boreal transition coasts of Nova Scotia (SNS) and the Gulf of Maine (GOM),, sets of sampling stations ranging from exposed shores through those of intermediate exposure to highly protected sites were 
occupied every 50-100 km along each of those coasts (Fig. 4). Adey and Hayek (2011) provide locations and description of those stations.

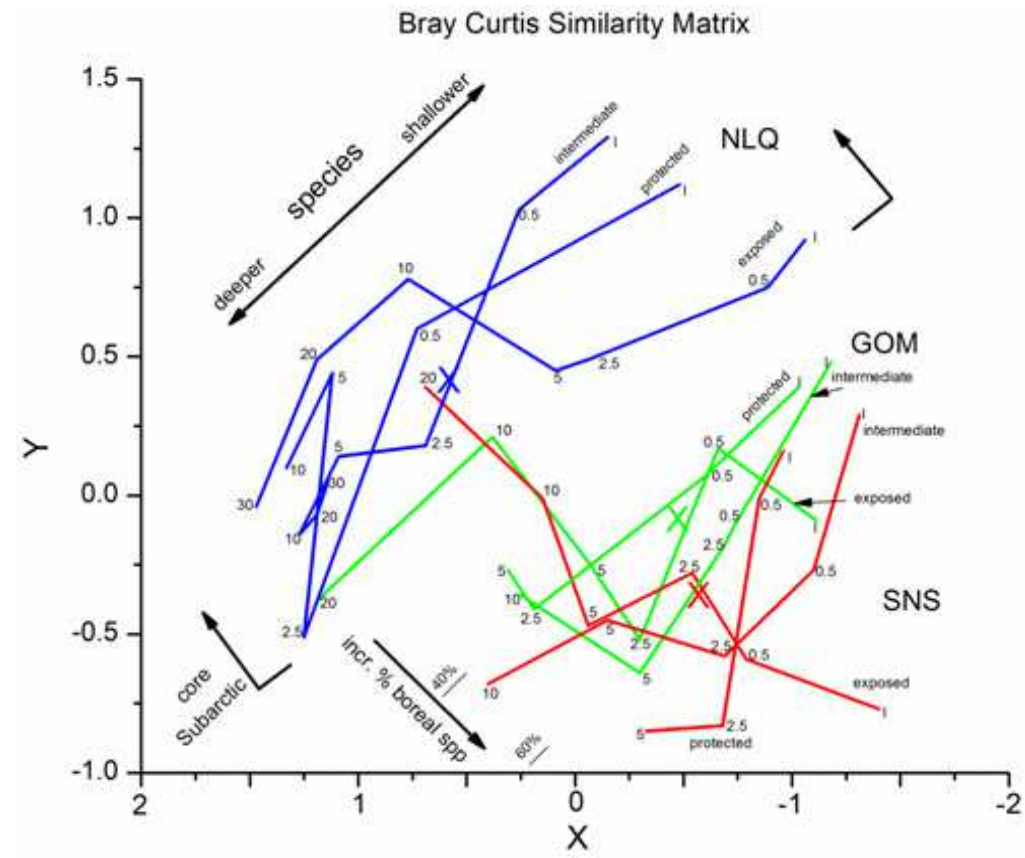

Fig. 3. Bray-Curtis multivariate similarity ordination plot. This graphic strongly separates NLQ (Subarctic) stations from the Gulf of Maine (GOM) and Southern Nova Scotia (SNS) stations in the transitional (Subarctic/Boreal) zone. The deepest depth zones at exposed stations in GOM and SNS crossover into the range of the Subarctic; this results from the dominance of Subarctic species related to a strong thermocline, and colder temperatures at depth.

At most stations, one or two one-meter-square PVC quadrats were dropped by SCUBA at each of six depth zones $(0.5,2.5,5,10,20,30 \mathrm{~m})$ depending mostly on substrate availability (see Adey and Hayek, 2011; Fig. 18) or occasionally the apparent photic limit (especially for GOM stations). In some cases, three or more replicate quadrats were taken at some depthzones when time was available.

The infralittoral zone (i.e., area between low water spring tides and low water neap tides) was also occupied at most stations, but a $1 / 10^{\text {th }} \mathrm{m}^{2}$ quadrat was used because of the frequent narrowness of the zone. Quadrat location at each station-depth zone was random, as typically the PVC square meter was dropped when the bottom came in view to the descending diver. After the quadrat was set on the bottom, a diver removed all macroscopic fleshy algae with a dive knife and placed them in a small mesh plastic dive bag.

Within each region, as discussed above, stations were selected for their wave exposure characteristics. As we shall demonstrate, wave exposure was a critical factor in determining macroalgal assemblages, and regional comparisons need to be based on similar exposure characteristics. All exposed stations occupied in this study occur on the open coast where they are subject to sea and swell at very large fetch and wide angle $\left(23^{\circ}-204^{\circ}\right)$. 


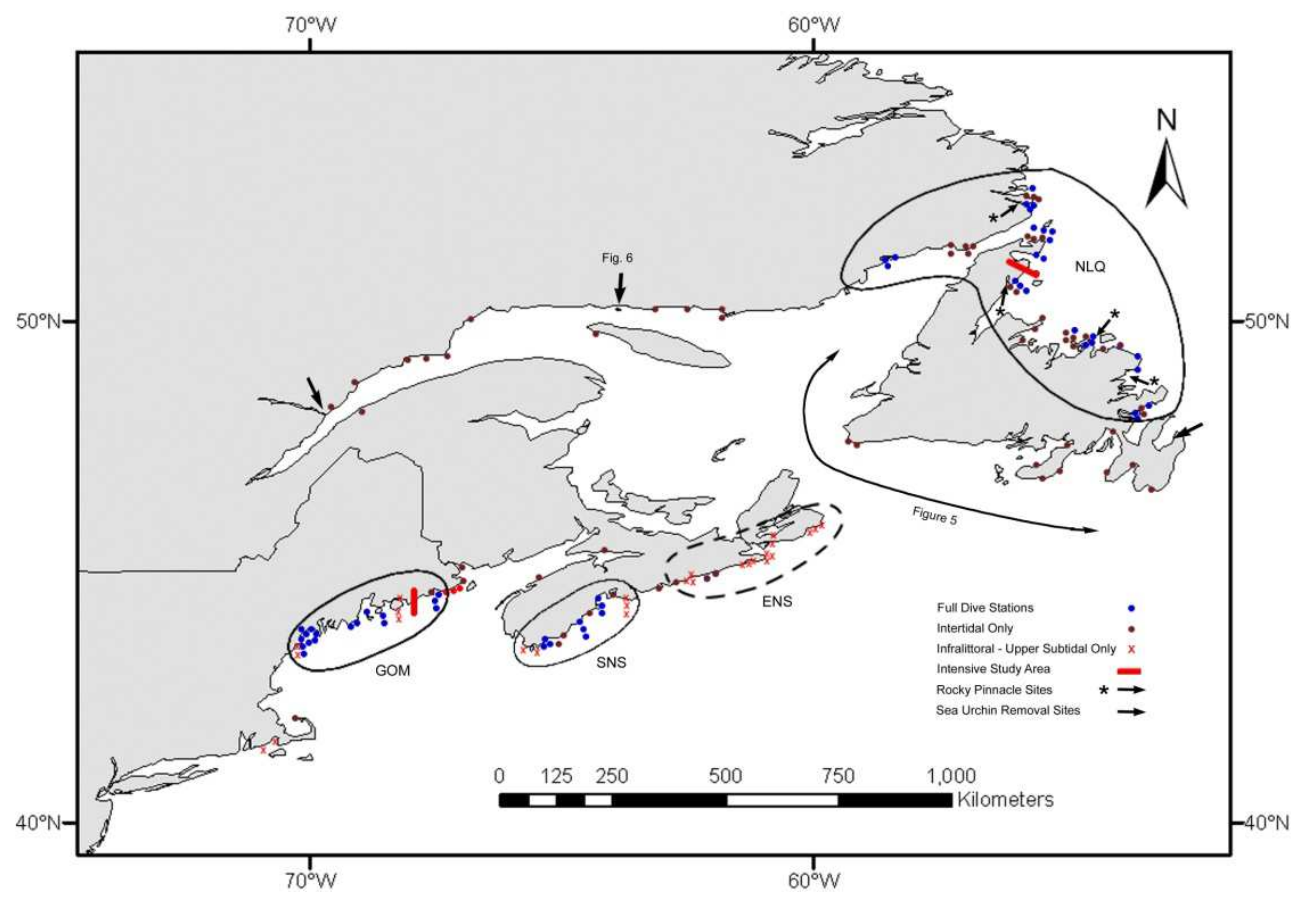

Fig. 4. Stations occupied in the Adey and Hayek (2005) project in the northwestern North Atlantic. The solid red dots are the intertidal stations occupied in the initial survey. The X's are infralittoral/0.5 m stations occupied primarily to compare Atlantic Nova Scotia, sea-ice affected shores with non sea ice shores. The solid blue dots are full dive stations and the two long dashes represent areas of numerous local stations and bottom mapping; the dash on the east side of the northern peninsula of NF represents two separate areas: Lunaire Road to the north and Canada Bay/Englee to the south

For the intermediate stations, open water exposure is more limited, a mean of $11-25^{\circ}$ as compared to $103-1170$ for the exposed shores; however, such stations are set back from the outer shore 1.0, 2.9, and $5.9 \mathrm{~km}$ respectively for NLQ, GOM, and SNS. In summary, open ocean exposure angle drops from a mean of $109^{\circ}$ for exposed stations to $17 \mathrm{o}$ for intermediate stations to $2^{\circ}$ for protected stations, while the exposure distance changes respectively from 0 to $3 \mathrm{~km}$ to $7 \mathrm{~km}$. There is no significant difference between NLQ, GOM, and SNS regions for exposed stations (Adey and Hayek, 2011).

\subsection{Data}

The data set consists of numerical abundances on 70 algal taxa collected at 7 depths in exposed stations, 5 depths in intermediate stations and 5 depths at protected stations. We chose to examine only 5 depths for each station type (exposed, intermediate and protected), so that comparisons could be made across taxa. Figure 4 shows the location of stations within depth zones.

A total of 68 samples were taken in the infralittoral, 20 samples were taken in the protected, 24 intermediate and 24 exposed. There were 71 samples taken at $0.5 \mathrm{~m}, 21$ protected area 
samples, 25 intermediate and 25 exposed area samples. Sixty nine samples were taken at a depth of $2.5 \mathrm{~m}, 16$ protected, 27 intermediate and 26 exposed. At a depth of $5 \mathrm{~m}, 75$ samples were taken, with 20 from protected sites, 26 from intermediate and 29 from exposed.

\subsection{SHE Analysis for biofacies identification (SHEBI)}

SHE analysis is the information - theoretic approach for biofacies identification and biodiversity analysis (Hayek and Buzas, 1997; 2010), composed of two variants. The first (SHEBI) variant or usage of SHE is for biofacies identification. After biofacies identification is complete, then within each biofacies so identified the second aspect termed SHECSI can be used to identify the community structure and ecological or evolutionary health status of the contained assemblage.

SHE is a methodology derived upon a conditional probabilistic basis with theorems from statistical entropy theory. No statistical testing of biofacies formation is required since each designated biofacies is a mathematical, closed, dynamic, faunal system and therefore replicable. For SHE, samples are accumulated (Hayek and Buzas, 1997) at separate depths over stations along the gradient from northernmost Newfoundland, through the Gulf of Maine to the southernmost zones of Nova Scotia (program available in Past ver 1.78 (2001) or from the author). At each step in this accumulation the values for additional new taxa, $\mathrm{S}$, along with an information measure we denote as $\mathrm{H}$, and an evenness measure $\mathrm{E}$, which uses taxon proportions, are each calculated. The boundary of each biofacies is determined from the changing values of estimated evenness of the biomass proportions as we accumulate over samples (Buzas and Hayek, 1998; Osterman et al. 2002; Hayek et al, 2007; Wilson, 2008). The entropy of the system is examined as the expected value of this information measure (Hayek and Buzas, 2010) and a comprehensive snapshot of the depth-related fauna is obtained. As evenness decreases, dominance increases, randomness over the taxon space increases and uncertainty and entropy must decrease within any unified system (Hayek et al., 2007; Hayek and Buzas, 2010). When we observe an increase on a plot of log standardized $\mathrm{N}$ versus $\mathrm{E}$, a new biofacies boundary has been reached.

\subsection{Conditional Biofacies Boundary Index (CoBBI)}

At any biofacies boundary, there is a total amount of change in species abundances, recognizable intuitively or quantitatively. This change is distinct from the subtle gradational taxon range overlap that is present throughout any ecological or paleoecological data set but never to our knowledge separately evaluated. After the boundary for each biofacies is determined, we developed a new index we call CoBBI (conditional biofacies boundary index). This index provides an examination of the taxon composition and abundance pattern only at the boundary. Calculations are based upon the total taxon assemblage accumulated just prior to and just after the biofacies boundary. In this way a total taxon change between biofacies is obtained. The change in abundance of each taxon across the boundary is used relative to the total change at the boundary. This index does not, as is usual, use the $100 \%$ change in the total assemblage over the entire set of samples and all its biofacies. This boundary-specific change is conditioned on only the chosen biofacies boundary, or specific faunal break, and thereby gives a picture of the entire assemblage within the biofacies of interest. With CoBBI we examine the prevalence of each species in the assemblages on either side of a biofacies boundary to obtain a total assemblage change between the biofacies 


\section{Results}

The SHE methodology for biofacies recognition was applied for each of the 5 depths at each of the set of stations that were designated Protected, Intermediate and Exposed. We accumulated through the longitudinal gradient from Newfoundland through the Gulf of Maine to Nova Scotia. It is of considerable importance in palaoecology that this is not a straight longitudinal line: the climate change shifts eastwards due to oceanic versus continental effects. In general, biofacies boundaries were determined that separated each of these regions from the other. In some cases, in particular for the infralittoral, the Newfoundland samples did not always form a continuum within a single biofacies. After determination of biofacies and boundaries between these regions, we applied CoBBI to obtain a total percentage change or difference between each pair of regions geographically and then to characterize the taxon assemblage within each biofacies and the change at the boundary. Results are given below and summarized in Tables 1 and 2. The results for each biofacies boundary and total change are presented in Table 1 . The taxa contributing to each of the boundaries are listed in Table $2 \mathrm{~A}$ and $\mathrm{B}$ with their percentage contribution to the total amount of change at the boundary.

$\begin{array}{llll}\text { Depth Site } & \text { Protected } & \text { Intermediate } & \text { Exposed } \\ \text { Infralittoral } & 1.139 \% & 199 \% & 199 \% \\ & 2.75 \% * 1 & 75 \%^{* 2} & 188 \% \\ 0.5 \mathrm{~m} & 1.199 \% & 200 \% & 182 \% \\ & 2.115 \% & 157 \% & 188 \% \\ 2.5 \mathrm{~m} & 1.196 \% & 200 \% & 100 \% \\ & 2.191 \% & 198 \% & 156 \% \\ 5 \mathrm{~m} & 1.195 \% & 200 \% & 200 \% \\ & 2.191 \% & 176 \% & 146 \%\end{array}$

* 1 There was not a biofacies boundary in the infralittoral zone between the Gulf of Maine and Nova Scotia. There was a change in the magnitude of the slope to indicate an assemblage change of less magnitude than that of a biofacies break. The biofacies boundary determined by SHE was between Newfoundland plus the first sample from Gulf of Maine and the remainder of Gulf of Maine. 168\% difference was observed for this break.

*2 There was not a boundary between Gulf of Maine and Nova Scotia samples. There was a boundary determined by SHE between the first 3 and the last 3 samples from Gulf of Maine. Then between Gulf of Maine and Nova Scotia there was a change in slope.

Table 1. Change in the taxon assemblage composition by depth and site between biofacies determined by SHE. 1. Newfoundland and Gulf of Maine biofacies ; 2. Gulf of Maine and Nova Scotia biofacies

\subsection{Newfoundland and Gulf of Maine} 3.1.1 Biofacies depth changes

Although especially for the infralittoral and $0.5 \mathrm{~m}$ depths, the entirety of the samples from Newfoundland did not always form a single biofacies, the actual boundaries determined by SHEBI between the end of the sample stations in Newfoundland and the beginning in Gulf of Maine were always clear cut. There was a total change in the taxon assemblage of $139 \%$ between those biofacies in protected sites and 199\% for intermediate and exposed sites (Table 1). Table 2A shows the most prominent contributors to this overall compositional change. In each of the infralittoral areas, Chondrus crispus, Chordaria flagelliformis and 
Devaleraea ramentacea were among those most important contributors to this overall total biofacies change but provided distinctly different contributions. While C. flagelliformis was the most dominant in protected infralittoral, this species dropped to second then third most dominant as sites increased in exposure. Likewise C crispus was only $11 \%$ of the total of the $139 \%$ change over protected sites while it increased to $45 \%$ then $47 \%$ from intermediate to exposed. $D$ ramentacea remained about $7 \%$ in protected and intermediate infralittoral but increased substantially to $27 \%$ dominance at the exposed infralittoral boundary between Newfoundland and Gulf of Maine.

A. Newfoundland to Gulf of Maine

1. Infralittoral

\section{Protected}

C flagelliformis 28\% (NLQ)

C purpureum 18\% (GOM)

C crispus $11 \%$ (GOM)

$N$ harveyi $11 \%$ (GOM)

$A$ arcta 7\% (NLQ)

$D$ ramentacea $7 \%$ (NLQ)

F distichus 8\% (NLQ)

\section{2. $0.5 \mathrm{~m}$}

\section{Protected}

C crispus 29\% (GOM)

F distichus 14\% (NLQ)

$D$ foeniculaceus (NLQ)

$D$ viridis $10 \%$ (NLQ)

A clathratum 9\%(NLQ)

A esculenta 9\% (NLQ)

P purpurea 6\%(GOM)

C flagelliformis 5\% (NLQ)

\section{3. $2.5 \mathrm{~m}$}

\section{Protected}

A clathratum 61\% (NLQ)

$D$ viridis $36 \%$ (NLQ)

\author{
Intermediate \\ C crispus $45 \%$ (GOM) \\ C flagelliformis 33\% (NLQ) \\ $D$ ramentacea $7 \%$ (NLQ) \\ Ceramium spp 5\% (GOM) \\ A $\operatorname{arcta} 5 \%$ (NLQ)
}

\section{Exposed}

C crispus $47 \%$ (GOM)

C flagelliformis 18\% (GOM)

$D$ ramentacea $27 \%$ (NLQ)

\author{
Exposed \\ A esculenta 31\% (NLQ) \\ S longicrurus $27 \%$ (GOM) \\ S latissima 13\%(GOM) \\ $L$ digitata 10\% (GOM) \\ C flagelliformis $8 \%$ (NLQ) \\ $D$ ramentacea 5\% (NLQ) \\ A $\operatorname{arcta} 5 \%$ (NLQ)
}

\section{Exposed}

Intermediate

A clathratum 33\% (NLQ)

C crispus $27 \%$ (GOM)

$D$ viridis $17 \%$ (NLQ)

$L$ digitata 13\% (GOM)

C rubrum 8\% (GOM)

$D$ viridis $5 \%$ (NLQ)

$S$ latissima 41\% (GOM)

A esculenta 18\% (NLQ)

$L$ digitata 10\% (GOM)

$S$ longicrurus 7\% (GOM)

A clathratum 5\% (GOM)

$D$ foeniculaceus 5\% (NLQ)

\section{Exposed}

Intermediate

$D$ viridis $30 \%$ (NLQ)

$S$ longicruris $43 \%$ (GOM)

A clathratum 20\% (NLQ)
S latissima 49\% (GOM)

$L$ digitata 26\% (GOM)

A esculenta 24\% (NLQ)

A clathratum 23\% (NLQ)

$S$ longicruris $21 \%$ (GOM) 
B. Gulf of Maine to Nova Scotia

5. Infralittoral

\section{Protected}

C crispus $40 \%$ (SNS)

F vesiculosus $23 \%$ (SNS)

$F$ distichus 14\% (SNS)

S latissima 9\% (SNS)

$N$ harveyi $11 \%$ (GOM)

A esculenta 10\% (GOM)

$F$ distichus 7\% (SNS)

$N$ multifidum 6\% (SNS)

6. $0.5 \mathrm{~m}$

\section{Protected}

Cofficinalis 21\% (SNS)

$S$ latissima 25\% (SNS)

C crispus $20 \%$ (GOM)

$D$ foeniculaceus $8 \%$ (SNS)

$D$ viridus 5\%(GOM)

\section{7. $2.5 \mathrm{~m}$}

\section{Protected}

$S$ dermatodea $28 \%$ (SNS)

$L$ digitata 20\% (SNS)

S latissima $14 \%$ (GOM)

C crispus $9 \%$ (SNS)

F serratus 6\% (SNS)

C fragile 5\% (SNS)

C crispus $5 \%$ (SNS)

8. $5 \mathrm{~m}$

\section{Protected}

A clathratum 40\% (GOM)

$L$ digitata 8\% (GOM)

P pseudoceranoides 5\% (SNS)

$S$ latissima 5\% (GOM)

N harveyi $13 \%$ (GOM)

$P$ pseudoceranoides 8\% (SNS)

\section{Intermediate}

C crispus $34 \%$

C officinalis 44\% (SNS)

A arcta 8\% (GOM)

\author{
Exposed \\ C crispus $25 \%$ (SNS) \\ C officinalis 19\% (SNS) \\ $D$ ramentacea $11 \%$ (GOM)
}

\author{
Intermediate \\ C crispus $24 \%$ (SNS) \\ C officinalis $44 \%$ (SNS) \\ C purpureum 10\% (GOM) \\ S latissima 15\% (SNS) \\ Exposed \\ A esculenta 41\% (GOM) \\ C officinalis $28 \%$ (SNS) \\ $L$ digitata $11 \%$ (SNS) \\ F serratus 5\% (SNS)
}

A sp. 5\% (SNS)

\section{Intermediate}

F serratus 26\% (SNS)

C officinalis 23\% (SNS)

S latissima 18\% (SNS)

S longicrusis $14 \%$ (GOM)

$L$ digitata 9\% (SNS)

\author{
Exposed \\ S longicruris $24 \%$ (GOM) \\ L digtata $20 \%$ (SNS) \\ $S$ latissima 18\% (GOM) \\ A esculenta $12 \%$ (GOM) \\ F serratus $7 \%$ (SNS)
}

Table 2. Taxon contributors to the biofacies change in assemblage composition of A.

Newfoundland to Gulf of Maine; B. Gulf of Maine and Nova Scotia. Relative percentages are only those that are over $5 \%$ of the total.

At a depth of $0.5 \mathrm{~m}$ Table 1 shows that CoBBI found well over $150 \%$ change at each of the biofacies for protected, intermediate and exposed sites. Here as Table 2A shows $C$ crispus was the most dominant contributor to the protected and intermediate biofacies boundaries but was not relevant for exposed. $C$ flagelliformis, though found at each type of station set at 
this depth was a minor contributor $(5 \%)$ in protected and exposed $(8 \%)$ but second most dominant $(18 \%)$ after $C$ crispus in intermediate. In the exposed areas at $0.5 \mathrm{~m}$ depth, Alaria esculenta (31\%) and Saccharina longicurus (27\%) were the two most important contributors.

Samples taken at $2.5 \mathrm{~m}$ formed distinct protected (196\% total change), intermediate $(200 \%)$ and exposed $(100 \%)$ biofacies between Newfoundland and Gulf of Maine. Agarum clathratum was identified by CoBBI as the most important contributor to these total changes in protected $(61 \%)$ and intermediate $(33 \%)$ areas while it was a minor player at only $5 \%$ in exposed. Desmarestia viridis was $36 \%$ in protected, $17 \%$ in intermediate and only $5 \%$ in exposed. C crispus was only a contributor $(27 \%)$ in intermediate and not relevant at this depth for other exposures (Table 2A).

Finally at $5 \mathrm{~m}$, the highest depth observed for this study, $D$ viridis was the most important contributor for both protected $(27 \%)$ and intermediate $(30 \%)$, while not relevant in exposed areas (Table 2A). Saccharina latissima $(27 \%)$ in protected, S longicruris $(43 \%)$ intermediate and $L$ digitata $(26 \%)$ in exposed were the second highest contributors. A clathratum was the third most important contributor to the biofacies total changes in protected $(23 \%)$ and intermediate $(20 \%)$ yet not relevant in exposed at this depth.

\subsection{Gulf of Maine and Nova Scotia \\ 3.2.1 Biofacies depth changes}

The boundaries between Gulf of Maine and Nova Scotia were in general clear cut except for infralittoral (Table 1). In cases in which SHE Analysis did not identify a boundary at the last station in Gulf of Maine, the Gulf of Maine plus one or two of the first Nova Scotia samples showed a change in slope rather than a distinct boundary. A change in the regression slope of $\ln N$ versus $\ln E$ indicates a community disruption of a lesser magnitude than the total change that results in a biofacies boundary. However, this was resolved when we re-ran SHEBI without replicates and used only the separate sampled stations; these totals are noted in Table 1. Table 2B shows that in the infralittoral $C$ crispus was again prominent at all exposure level sites comprising $40 \%, 34 \%$ and $25 \%$ respectively of each of the total changes identified by CoBBI from protected to exposed. Corallina officinalis, though not relevant in protected sites, was the most important contributor for intermediate $(44 \%)$ and second most (19\%) in exposed. Neither C flagelliformis nor D ramentacea were contributors to the infralittoral biofacies boundary changes in these areas, except for exposed when $D$ ramentacea was $11 \%$.

Each of the total boundary changes was well over $100 \%$ for the $0.5 \mathrm{~m}$ depth. Saccharina latissima (25\%), C. officinalis (44\%) and Alaria esculenta(41\%) provided the most important contributions to the total changes for protected, intermediate and exposed respectively. $C$ officinalis was second at both protected (21\%) and exposed $(28 \%)$. C. crispus was $20 \%$ in protected and $24 \%$ in intermediate but had no involvement for exposed sites (Table 2B).

At the $2.5 \mathrm{~m}$ depth, sampling between the biofacies of Gulf of Maine and Nova Scotia there was less dominance at each level of exposure. At protected sites, Saccorhiza dermatodea (28\%) and $L$ digitata $(20 \%)$ were the two taxa providing the most input into the total biofacies change. The top two contributors were Fucus serratus (26\%) and Corallina officinalis (23\%) for intermediate with A longicruris (24\%) and L digitata (20\%) for exposed (Table 2B).

For the $5 \mathrm{~m}$ depth, protected sites only, A clathratum at $40 \%$ of the total change of $195 \%$ contributed importantly. For the intermediate sites, L digitata was $21 \%$ of the total and $F$ serratus was $18 \%$, with S latissima (15\%) and S longicruris (14\%) and Neosiphonia harveyi $(13 \%)$ of equivalent importance to the total biofacies change of $176 \%$. For exposed $5 \mathrm{~m}$ sites $S$ 
latissima at $33 \%$ and $L$ digitata at $34 \%$ were equivalent contributors to the total $146 \%$ assemblage change at the biofacies boundary (Table 2B).

\section{Discussion}

As we have shown, both classical and modern coastal marine biogeography are based in sea surface temperatures. These are usually correlated with qualitative or semi-quantitative information on assemblages of organisms, mostly based in the presence or absence of key species. The temperature data have been measured over perhaps a century and found to be decreasing in abundance and accuracy prior to mid 20th century. Recent improvements in satellite sensing have greatly increased the number of SST data points both spatially and seasonally, and the expanding number of field researchers has increased logarithmically The amount of ecological and biodiversity information ecological information (Spalding, 2007). Nevertheless, little macroevolution has occurred during the half-century to a century of data accumulation since massive climate and physical shorelines shifts have occurred in both Tertiary and Pleistocene time, these biogeographic and ecogeographic regions are simply snapshots in time. Also, we now recognize that human activity over the last five centuries has transported large numbers of alien species, many of which have established populations in new regions, significantly disrupting local ecosystems (Johnson et al, 2011). As Adey and Hayek (2011) have shown, a major focus of attention of shore ecologists (for the coasts of Nova Scotia and the Gulf of Maine), has likely been subject to significant invasions of European species. Some of these were suspect-introduced species, but most were unrecorded, even though technically historical.

As Adey and Steneck (2001) have demonstrated, assemblages of organisms and the ecosystems they form have built the primary regional groupings of shore organisms, for classical marine biogeography changing climates and sea levels. The increasing sophistication of our understanding of both climate and sea levels, at least in the Pleistocene and Tertiary, provide a rational basis for expanding the TM. The TM was based on CLIMAP SST for the Pleistocene, but more recent and sophisticated models, such as MARGO (MARGO Project Members, 2009; Hargreaves et al, 2011) show that increasing precision of the TM is possible. Because the TM is also based on coastal area, knowledge of past sea levels is critical; these are also improving with time (Kominz, 2001).

Although current methods in geology and paleontology for biofacies recognition are predominantly quantitative, for example, cluster analysis and scaling methods, these were developed for other purposes. This quantitative approach to biofacies recognition uses and adapts methods that were derived for other problems or for general usage but not specifically tailored to the intricacies of identification of biofacies. Thus SHE Analysis with SHEBI is unique in its singular purpose. SHEBI is currently the only comprehensive methodology for defining biofacies in a precise and replicable manner. In paleoecological and ecological study, the identification of unique biofacies boundaries and the structure of the assemblages on either side of those boundaries is critical to identifying environmental changes with time. CoBBI provides a comprehensive and new assessment of assemblage composition at each biofacies boundary. Recognition that distinctive fossil taxon assemblages can be found in certain lithofacies is a dominant theme in paleontology. Such assemblages are utilized to provide information on the environmental controls of the observed distributions of taxa and for creating a framework amenable to paleoenvironmental interpretations. 
At this time, our understanding of shore biogeography can be improved significantly by extending the TM analysis back into the Tertiary and merging the physical/climatic status of fossil shoreline with paleoecology. To do this, the understanding of macro-shore evolution as a result of plate tectonics and sea level change is necessary. Our understanding of plate tectonic processes, and particularly the changing of assemblages in time relative to shifting plates and shorelines (eg. Brenchley and Harper, 1998), is rapidly improving. Combined with sea level and climate variation data with time these can provide a solid basis for building a new TM that expands from species evolution to genera and families at least back to the mid Tertiary. When this basic structural information is considered along with our increasing knowledge of molecular biology and macroevolutionary processes, a revolution in our understanding of both ecology and paleoecology is imminent.

\section{Conclusion}

The results of the present study provide a unique view and test of the TM. This final test of the model conclusively shows its wide-ranging applicability. The importance of biofacies recognition has been a major theme in geology and paleontology ever since Gressley introduced the term facies in 1838. Recognition and analysis of assemblages in the fossil record is one of the dominant themes in paleoecology. It is apparent that spatial and temporal distribution of assemblages in the lithologic record create a framework that is amenable to paleoenvironmental interpretations. By applying SHEBI to our the sample data from the three regions proposed and previously tested to compose the TM we have new and conclusive evidence that the biofacies within the TM are scientifically replicable and distinct. When only presence-absence data was used in the past to define the entire North Atlantic as a single biofacies, this comprised a partial amount of information and not a quantitative test. Adey and Steneck (2001) advocated, and we used, not merely the species list and richness but species composition in the form of relative abundances and their differences. This recommendation of Adey and Steneck (2001) has proved worthwhile.

\section{References}

Adey, W., \& Hayek, L.C. 2011. Elucidating Marine Biogeograhy with Macrophytes: Quantitative analysis of the North Atlantic supports the Thermogeogrpahic Model and demonstrates a distinct Subarctic Region in the northwestern Atlantic. Northeastern Naturalist 18: 1-12.

Adey, W. H., \& Hayek, L. C. 2005, The biogeographic structure of the western North Atlantic rocky intertidal, Cryptogamie, Algol., v. 26, no. 1, p. 35-66.

Adey, W. \& Steneck, R. 2001. Thermogeography over time creates biogeographic regions: a temperature/space/time-integrated model and an abundance-weighted test for benthic marine algae. Journal of Phycology. 37: 677-98.

Adey, W. \& Hayek, L.C. 2005. The biogeographic structure of the western North Atlantic rocky intertidal. Crypogamie Algol. 26(1): 35-66.

Adey, W., Lindstrom, S., Hommersand, M. \& Muller, K. 2008. The biogeographic origin of Arctic endemic seaweeds: a thermogeographic view. Journal of Phycology. 44: 1384-94.

Bassi, D. \& Nebelsick, J. 2010. Components, facies and ramps: redefining upper Oligocene shallow water carbonates using coralline red algae and larger foraminifera 
(Venetian area northeast Italy) Paleogeography Palaeocliminatology and Palaeoecology 295: 258-280.

Brenchley, P. \& Harper, D, 1998. Palaeoecology: Ecosystems, environments and evolution. Chapman and Hall. London. 402pp.

Briggs, J. 1974. Marine Zoogeography. McGraw Hill. New York. 475 pp.

Briggs, J. 1995. Global Biogeography. Elsevier. Amsterdam. 452 pp.

Buzas, M.A., \& Hayek, L.C. 1998, SHE Analysis for Biofacies Identification, Journal of Foraminiferal Research, v. 28, no. 3, p. 233-239.

CLIMAP Project Members. 1976. The surface of the ice-age earth. Science 191: 113-7.

Gressley, A. 1838. Observations geologiques sur le Jura Soleurois. Schweizer Gesellgesamten Naturwiss. Neue Demkschr. 2: 1-112.

Hammer, O., Harper, D.A.T., \& Ryan, P.D. 2001. PAST: Palaeontological Statisticis software package for education and data analysis. Palaeontologia Electronica. 4(1):9. Version 1.78, 2008.

Hargreaves, J., Paul, A., Ohgaito,R., Abe-Ouchi, A., \& Annan, J. 2011. Are paleoclimate model ensembles consistent with the MARGO data synthesis? Clim. Past? Discuss. 7775-2011.

Hayek, L. C. \& Buzas, M.A., 1997a, Surveying Natural Populations, Columbia Univ. Press, NY, $563 \mathrm{p}$.

Hayek, L.C. \& M.A. Buzas. 1997b. SHE Analysis: An integrated approach to the analysis of forest biodiversity. Pages 311-322 In F. Dallmeier and J.A. Comisky, eds. Forest Biodiversity Research, Monitoring and Modeling: Conceptual Background and Old World Case Studies. Washington D.C. Unesco, Paris and The Parthenon Publishing Group.

Hayek, L.C. \& M.A. Buzas, 2010 Surveying Natural Populations: Quantitative tools for biodiversity assessment, Columbia Univ. Press, NY, 590p.

Hayek, L.C., Buzas, M.A. \& Osterman, L. 2007. Community structure of foraminiferal communities within temporal biozones in the Western Arctic Ocean, Journal of Foraminiferal Research, v. 37, p. 33-40.

Johansen, H.W. 1981. Coralline Algae, a First Synthesis. CRC Press. Boca Raton. 239 pp.

Kominz, M. 2001. Sea Level Variations Over Geological Time. Academic Press. doi 10.1006.2001.0255.

Longhurst, A. 1998. Ecological Geography of the Sea. Academic Press. New York. 398 pp.

Mana, D., 2005, A test application of the SHE method as a biostratigraphical parameter, Geo. Alp., v. 2, p. 99-106.

MARGO Project Members. 2009. Constraints on the magnitude and patterns of ocean cooling at the last glacial maximum. Nature GeoScience 2: 127-132.

Osterman, L., Buzas, M. A., \& Hayek, L. C., 2002, SHE analysis for biozonation in western Arctic sampling. Palaios, v. 17, p. 297-303.

Rosenzweig, M. 1995. Species Diversity in Space and Time. Cambridge University Press. Cambridge. $436 \mathrm{pp}$.

Vermeij. C. 1978. Biogeography and Adaptation. Harvard Univ. Press. Cambridge, Mass. $332 \mathrm{pp}$.

Wilson, B., 2008, Using SHEBI (SHE Analysis for Biozone Identification): To Proceed from the Top Down or the Bottom Up? A Discussion Using Two Miocene Foraminiferal Successions from Trinidad, West Indies: Palaios, v. 23, p. 636-644. 


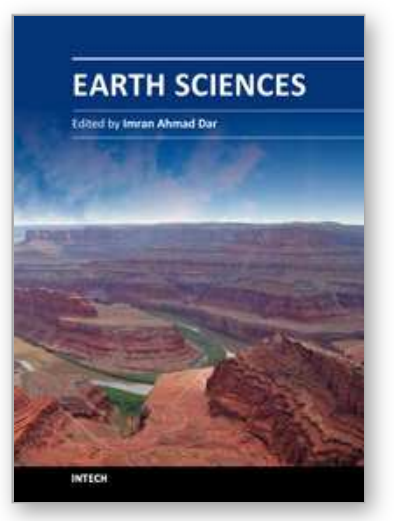

\author{
Earth Sciences \\ Edited by Dr. Imran Ahmad Dar
}

ISBN 978-953-307-861-8

Hard cover, 648 pages

Publisher InTech

Published online 03, February, 2012

Published in print edition February, 2012

The studies of Earth's history and of the physical and chemical properties of the substances that make up our planet, are of great significance to our understanding both of its past and its future. The geological and other environmental processes on Earth and the composition of the planet are of vital importance in locating and harnessing its resources. This book is primarily written for research scholars, geologists, civil engineers, mining engineers, and environmentalists. Hopefully the text will be used by students, and it will continue to be of value to them throughout their subsequent professional and research careers. This does not mean to infer that the book was written solely or mainly with the student in mind. Indeed from the point of view of the researcher in Earth and Environmental Science it could be argued that this text contains more detail than he will require in his initial studies or research.

\title{
How to reference
}

In order to correctly reference this scholarly work, feel free to copy and paste the following:

Lee-Ann C. Hayek and Walter H. Adey (2012). The Thermogeographic Model in Paleogeography: Application of an Abiotic Model to a Plate Tectonic World, Earth Sciences, Dr. Imran Ahmad Dar (Ed.), ISBN: 978-953307-861-8, InTech, Available from: http://www.intechopen.com/books/earth-sciences/the-thermogeographicmodel-in-paleogeography-application-of-an-abiotic-model-to-a-plate-tectonic-wor

\section{INTECH}

open science | open minds

\author{
InTech Europe \\ University Campus STeP Ri \\ Slavka Krautzeka 83/A \\ 51000 Rijeka, Croatia \\ Phone: +385 (51) 770447 \\ Fax: +385 (51) 686166 \\ www.intechopen.com
}

\author{
InTech China \\ Unit 405, Office Block, Hotel Equatorial Shanghai \\ No.65, Yan An Road (West), Shanghai, 200040, China \\ 中国上海市延安西路65号上海国际贵都大饭店办公楼405单元 \\ Phone: +86-21-62489820 \\ Fax: $+86-21-62489821$
}


(C) 2012 The Author(s). Licensee IntechOpen. This is an open access article distributed under the terms of the Creative Commons Attribution 3.0 License, which permits unrestricted use, distribution, and reproduction in any medium, provided the original work is properly cited. 